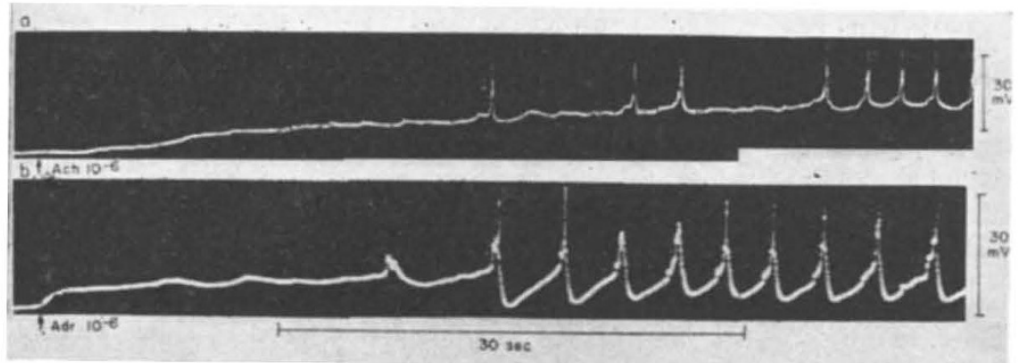

Fig. 1 Membrane potential changes and spike activity in the presence of: $(a)$ acetylcholine $($ Ach $) 10^{-6} ;(b)$ adrenalin (Adr) $10^{-6}$. Pig oesophagus muscularis mucosæ. Sucrose gap technique. Temp., $35^{\circ} \mathrm{C}$.

and electrical properties of these two muscles revealed no qualitative differences ${ }^{6}{ }^{7}$. Experiments designed to detect differences in ion distribution, permeability and electrogenic sodium pump activity ${ }^{3}$ are in progress.

Some of this work was done in the Department of Physiology, University of Illinois.

Department of Zoology,

University of Melbourne.

${ }^{1}$ Bülbring, E., J. Physiol., 135, 412 (1957).

2 Burnstock, G., J. Physiol., 143, 165 (1958a).

${ }^{3}$ Burnstock, G., J. Physiol., 143, 183 (1958b).

${ }^{4}$ King, C. E., and Robinson, M. H., Amer. J. Physiol., 143, 325 (1945).

${ }^{5}$ Burnstock, G., and Straub, R. W., J. Physiol., 140, 156 (1958).

'Burnstock, G., and Prosser, C. L., Amer. J. Physiol. (in the press).

${ }^{7}$ Prosser, C. L., and Burnstock, G., Amer. J. Physiol. (in the press).

\section{Accumulation of Substrate by Isolated Rat Diaphragm: a Possible Mechanism for the Anti-Inflammatory Action of Corticosteroids}

Adrenalectomy enhances, and adrenal cortical hormone depresses, the incorporation of carbon-14 from amino-acids, and from amino-acid precursors, into the protein of isolated rat diaphragm ${ }^{1,2}$. These changes are, at least in part, the result of a direct

Table 1. EFFEcT OF ADRENALECTOMY AND CORTISONE ON THE ACCUMUlation OF CARBON-14 LABELlED SUBSTRATE BY ISOLATED 'INTACT' RAT DIAPHRAGM

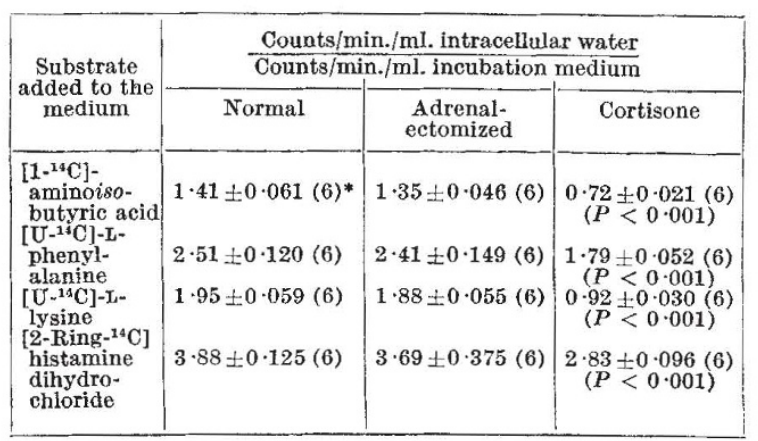

Diaphragms from normal, adrenalectomized (4 days) and cortisonetreated ( $2 \mathrm{mgm}$./day for 4 days) rats were incubated with shaking for $2 \mathrm{hr}$. at $37^{\circ}$ in $5 \mathrm{ml}$. Krebs-Henseleit bicarbonate buffer. Concentration of substances used were: $\left[11^{14} \mathrm{C}\right]$-aminoisobutyric acid, $1.37 \times 10^{-4} M$; L-phenylalanine, $4.9 \times 10^{-5} M$; L-lysine, $6.55 \times$ $10^{-5} M$; histamine, $1 \times 10^{-4} M$. The radioactivity added was, in each experiment, $0.5 \mu \mathrm{c}$. $/ \mathrm{ml}$. Accumulation of soluble radioactivity was determined by extracting diaphragm with $10 \mathrm{ml}$. of 1 per cent trichloracetic acid at $100^{\circ}$ for 5 min. Aliquots of the soluble extract and of the incubation medium were diluted, plated and assayed with a gas-flow Geiger counter. The results are expressed as the ratio of counts/min./ml. intracellular water (assumed to be 75 per cent of wet weight) to counts $/ \mathrm{min}$. $/ \mathrm{ml}$. incubation medium; a ratio greater The value of $\boldsymbol{P}$ for a difference which is significant is given in brackets.

* Mean $\pm S . E$. of mean; number of observations in parenthesis. effect on protein biosynthesis ${ }^{1,3}$. Whether corticosteroids also offect protein synthesis indirectly by influencing amino-acid transport and accumulation is not known. The possibility was tested by measuring the penetration and accumulation of $\left[1^{-14} \mathrm{C}-\right]$-aminoisobutyric acid ${ }^{4}$, a non-utilizable amino-acid analogue, and of the utilizable amino-acids [U- $\left.{ }^{14} \mathrm{C}\right] \mathrm{L}$-phenylalanine and [U-14 $\mathrm{C}$ ] L-lysine, by 'intact' diaphragms ${ }^{5}$ isolated from normal, adrenalectomized, and cortisone-treated rats.

Cortisone significantly depressed accumulation in skeletal muscle of [1-14 C]-aminoisobutyric acid and of L-phenylalanine and L-lysine; adrenalectomy was without effect on this process (Table 1). It is concluded that increased protein biosynthesis after adrenalectomy is not due to stimulation of aminoacid penetration; decreased accumulation could contribute to the depression in protein synthesis after cortisone.

The decrease in amino-acid penetration after cortisone has another and possibly more important implication, namely, that the mechanism of cortico. steroid protection against inflammation and allergy may involve exclusion from cells of inciting humoral substances, similar in structure to the amino-acids, as for example histamine. This possibility was tested. Cortisone decreased accumulation of carbon-14 histamine by isolated muscle (Table 1). The biochemical basis of the anti-inflammatory and antiallergic action of corticosteroids may be a decrease in the penetration into cells of a local humoral substance (histamine or like histamine) which in turn serves as the stimulus for tissue changes in inflammation and. allergy.

This investigation was aided in part by a grant (A-1653) from the National Institutes of Health, and by the Wallace C. and Clara A. Abbott Memorial Fund of the University of Chicago.

Department of Physiology,

University of Chicago.

${ }^{1}$ Wool, I. G., and Weinshelbaum, E. I., Amer. J. Physiol., 197, 1089 (1959).

${ }^{2}$ Wool, I. G., and Weinshelbaum, E. I., Amer. J. Physiol., 198, 360 (1960).

${ }^{3}$ Wool, I. G., and Weinshelbaum, E. I., Amer. J. Physiol., 198(5), (1960)

${ }^{4}$ Kipnis, D. M., and Noall, M. W., Biochim. Biophys. Acta, 28, 226 (1958).

' Kipnis, D. M., and Cori, C. F., J. Biol. Chem., 224, 681 (1957).

\section{IMMUNOLOGY}

\section{A Possible Basis for Immunological Tolerance}

The following hypothesis is based on the possibility that, although the mechanism for the entrance of macromolecules into the cell may be the relatively non-specific phenomenon of pinocytosis, the mechanisms for secreting materials out of the cell may be specific. These unknown (probably active) transport mechanisms will, for ease in referring to them, be called 'secretases', by analogy to the bacterial permeases, which are concerned with entry rather than exit mechanisms ${ }^{1}$. Simple diffusion would account for only a small part of the macromolecular 